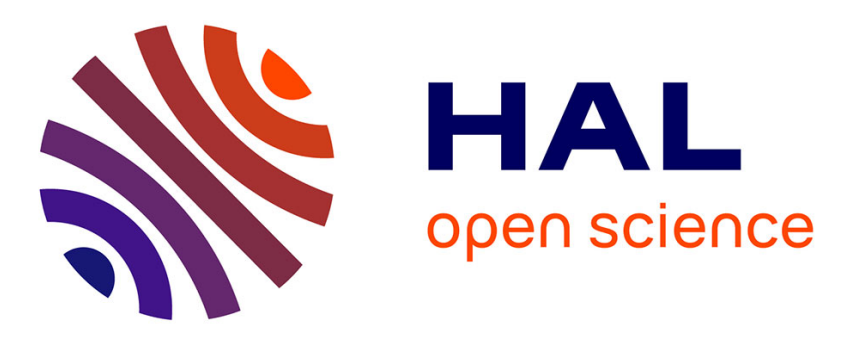

\title{
Pre-almond supplemental forage improves colony survival and alters queen pheromone signaling in overwintering honey bee colonies
}

Mark J. Carroll, William G. Meikle, Quinn S. Mcfrederick, Jason A. Rothman, Nicholas Brown, Milagra Weiss, Zachary Ruetz, Erica Chang

\section{To cite this version:}

Mark J. Carroll, William G. Meikle, Quinn S. Mcfrederick, Jason A. Rothman, Nicholas Brown, et al.. Pre-almond supplemental forage improves colony survival and alters queen pheromone signaling in overwintering honey bee colonies. Apidologie, 2018, 49 (6), pp.827-837. 10.1007/s13592-018-0607-x . hal-02367481

\section{HAL Id: hal-02367481 https://hal.science/hal-02367481}

Submitted on 18 Nov 2019

HAL is a multi-disciplinary open access archive for the deposit and dissemination of scientific research documents, whether they are published or not. The documents may come from teaching and research institutions in France or abroad, or from public or private research centers.
L'archive ouverte pluridisciplinaire HAL, est destinée au dépôt et à la diffusion de documents scientifiques de niveau recherche, publiés ou non, émanant des établissements d'enseignement et de recherche français ou étrangers, des laboratoires publics ou privés. 


\title{
Pre-almond supplemental forage improves colony survival and alters queen pheromone signaling in overwintering honey bee colonies
}

\author{
Mark J. Carroll ${ }^{1}$, William G. Meikle ${ }^{1}$, Quinn S. McFrederick ${ }^{2,3}$, \\ Jason A. RothmaN ${ }^{3}$, Nicholas Brown ${ }^{1}$, Milagra Weiss ${ }^{1}$, Zachary RuEtz ${ }^{1}$, Erica CHANG ${ }^{1}$ \\ ${ }^{1}$ Carl Hayden Bee Research Center, USDA-ARS, Tucson, AZ 85719, USA \\ ${ }^{2}$ Department of Entomology, University of California Riverside, Riverside, CA 92521, USA \\ ${ }^{3}$ Graduate Program in Microbiology, University of California Riverside, Riverside, CA 92521, USA
}

Received 22 July 2017 - Revised 12 August 2018 - Accepted 4 October 2018

\begin{abstract}
Supplemental forage can be used to provide nutrition to bees during winter dearth. We examined the effects of supplemental forage on colony performance, colony survival, worker quality, and queen pheromone signaling in Nosema ceranae-infected overwintering colonies. Colonies were either supplemented with rapini or left unsupplemented for 1 month before almond pollination. Unsupplemented colonies experienced higher mortality than supplemented colonies. Supplemental forage did not affect colony performance, worker mass, or hypopharyngeal gland protein content. However, supplemented queens released more of three queen QMP and QRP compounds (4-hydroxy-3-methoxyphenylethanol, methyl oleate, and 1-hexadecanol) that promote queen care among workers. In addition, colonies that survived almond pollination thermoregulated their hives more than colonies that failed. Supplemental forage may prepare overwintering colonies for the stresses of early spring pollination.
\end{abstract}

\section{QMP / continuous monitoring / hive temperature / thermoregulation / Nosema ceranae}

\section{INTRODUCTION}

Honey bee colonies in temperate and subtropical climates face prolonged stress from poor forage during winter dearth. Colonies adjust to winter by producing long-lived winter bees, reducing queen oviposition and brood rearing, and altering thermoregulation (Fluri et al. 1982; Kronenberg and Heller 1982; Mattila and Otis 2007; Döke et al. 2015). Despite these adaptations, overwintering colonies remain vulnerable. In

Electronic supplementary material The online version of this article (https://doi.org/10.1007/s13592-018-0607-x) contains supplementary material, which is available to authorized users.

Corresponding author: M. Carroll,

Mark.Carroll@ars.usda.gov

Manuscript Editor: James Nieh recent years, most seasonal colony losses have occurred from late fall through early spring (Seitz et al. 2015; Döke et al. 2015). To reduce stress, beekeepers often supplement overwintering bees with pollen substitutes that provide proteins, lipids, vitamins, and other nutrients normally found in pollen (DeGrandiHoffman et al. 2008; Brodschneider and Crailsheim 2010). These substitutes can be used to build fall bee populations, support winter nutrition, and promote worker production before spring forage is available (DeGrandi-Hoffman et al. 2008). Nonetheless, some studies have found that colonies do not perform as well on pollen substitute as on diets containing real pollen (Standifer et al. 1973; Al-Ghamdi et al. 2011; DeGrandi-Hoffman et al. 2010, 2016).

One alternative to pollen substitutes is supplemental forage (SF) (Decourtye et al. 2010; 
DeGrandi-Hoffman et al. 2016; Lundin et al. 2017). Three approaches for overwintering colonies have been suggested: (1) fall SF during winter bee production, (2) mid-winter SF before the first spring forage, and (3) SF during the first spring forage (Decourtye et al. 2010; DeGrandiHoffman et al. 2016; Alaux et al. 2017). The second approach is well suited to colonies used for California almond pollination. The limited forage available in winter around orchards is often insufficient to support the more than 1.7 million colonies used in almond pollination (SimoneFinstrom et al. 2016; Lundin et al. 2017). However, almond-bound colonies are often pre-staged in locations capable of supporting winter-blooming plants. A recent study has demonstrated that midwinter SF improves host immunity, resistance to Nosema, worker nutrition, and colony survival (DeGrandi-Hoffman et al. 2016). However, SF has not yet been examined as a nutritional support for colonies used in almond pollination.

We evaluated the effects of mid-winter SF on colony performance, pheromone signaling, and worker health. For SF, we chose rapini (Brassica rapa rapa), a freeze-tolerant mustard that flowers during the winter in the Southwestern United States (DeGrandi-Hoffman et al. 2016). Like related mustards, rapini serves as a nutritious pollen source for bees (Rollin et al. 2013). We provided SF to colonies infected by Nosema ceranae, a major pathogen that seasonally peaks during overwintering in subtropical locales, and is partially ameliorated by dietary pollen (Chen et al. 2012; DiPasquale et al. 2013; Jack et al. 2016). We also used continuous monitoring to measure changes in colony thermoregulation effort (Meikle et al. 2016). During winter, broodrearing colonies maintain higher hive temperatures than broodless colonies (Harrison 1987; Wang et al. 2016). Finally, we examined the effects of SF on communication pathways that maintain a viable queen. Queens release queen mandibular pheromone (QMP) and queen retinue pheromone (QRP) to promote queenright behaviors, suppress supersedure, and solicit worker care (Slessor et al. 1988; Naumann et al. 1991; Pankiw et al. 1998; Pettis et al. 1995, 1997; Keeling et al. 2003). Here, we report how mid-winter SF affects queen signaling to colony workers.

\section{MATERIALS AND METHODS}

\subsection{Honey bee colonies and forage treatments}

Field colonies were used to assess the effects of mid-winter SF on overwintering colonies later used to pollinate almonds (see Online Resources 1 and 2 for timeline and apiary locations). In November 2015, single deep colonies consisting of 12-18,000 workers, 2-3000 brood, and an Italian queen were assembled at a pre-treatment apiary (University of Arizona Campus Agricultural Center, Tucson, Pima County, AZ, USA; 32.27636, - 110.93845, $719 \mathrm{~m})$. Colonies were not treated for Nosema spp. or Varroa mites during the study; however, periodic checks indicated that phoretic mite infestations did not exceed $5 \%$. Sentinel colonies with front loader pollen traps (Brushy Mountain, Moravian Falls, NC, USA) were placed among experimental colonies to monitor corbicular pollen flow.

Colonies were placed in four successive forage environments (pre-treatment apiary, pre-almond forage treatment sites, almonds, and post-almond holding yard) and evaluated at four time points (pre-forage, post-forage, post-almond, and postholding yard) from December 2015 to April 2016). On December 30th, 32 experimental colonies and 8 sentinel colonies were randomly assigned to 1 of 4 forage treatment sites for 1 month. Two forage-supplemented (FS) sites (RRE and RRW) were located near 2 ha of flowering rapini (Brassica rapa spp. rapa) at the Red Rock Agricultural Center (University of Arizona Campus Agriculture, Pima County, AZ, USA) while two unsupplemented (UF) sites (MACN and MACS) were located on forage poor agricultural lands at the Maricopa Agricultural Center (University of Arizona, Pinal County, AZ, USA; see Online Resource 2). Honey bees were observed foraging on a limited array of forage at all sites, but no crops aside from rapini were in bloom (see Online Resource 3). At the end of the forage treatment, all colonies were evaluated and moved to an almond orchard near Blackwell's Corner (Wonderful Farms, Kern County, CA, USA; almonds flowered from 2/10/ 16 to $3 / 2 / 16$ ). After the bloom, all colonies were 
evaluated and moved to a holding yard with limited forage near Keck's Corner (Kern County, CA, USA). After 1 month, the surviving colonies were evaluated.

\subsection{Colony sampling and evaluations}

At each time point, 50 nest workers from brood frames and $2 \mathrm{~g}$ subsamples of stored pollen and honey were taken from each colony and frozen for later analyses. The total mass of colony adult workers was calculated as the difference between the colony mass with and without adult workers. The total comb areas occupied by brood and stored pollen cells were estimated by frame photograph analysis using ImageJ version 1.47 software (W. Rasband, National Institutes of Health, USA; Meikle et al. 2016).

\subsection{Individual worker mass and HPG protein content}

At each time point, three colony nest workers were examined to assess worker mass (without the gut contents) and the protein contents of hypopharyngeal glands (HPG) used to feed young larvae (Hrassnigg and Crailsheim 1998). HPGsoluble protein contents were quantified by a bicinchonic acid (BCA) protein assay using the kit protocol (Pierce Thomas Scientific, MA, USA).

\subsection{Queen pheromone transfer from the queen to the retinue workers}

QMP and QRP were quantified by a novel method that measured queen pheromone releases to retinue workers (Seeley 1979; Naumann et al. 1991; Keeling et al. 2003). Approximately 60 workers were enclosed with the queen on comb under a double screen mesh push-in cage. This barrier allowed the enclosed workers to interact with the queen but prevented caged workers from transferring QMP to outside workers. After $2 \mathrm{~h}$, bees outside the cage were brushed off and the frame briefly lowered into a container with dry ice to partially immobilize the enclosed bees. The queen was quickly transferred back to the colony and all the remaining bees collected on dry ice. No distinction was made between workers that actively interacted with the queen and workers that did not. Retinue samples were collected from each colony at each time point and stored in the dark at $-80{ }^{\circ} \mathrm{C}$ to limit compound degradation..

QMP and QRP compounds were extracted, derivatized, and analyzed by EI GC-MS (after Slessor et al. 1990). Sample workers were ground in liquid nitrogen and transferred to a glass Mason jar containing $30 \mathrm{~mL}$ diethyl ether and $100 \mu \mathrm{g}$ cis-10-heptadecenoic acid (internal standard, Sigma, St. Louis, MO, USA). Jar contents were then sealed, wrapped in foil, and extracted in the dark at $25{ }^{\circ} \mathrm{C}$ for $20 \mathrm{~h}$. Then, $1000 \mathrm{~mL}$ supernatant was transferred into a crimp vial, dried down, and silylated in the dark with $150 \mu \mathrm{L}$ BSA (N,Obis(trimethylsilyl)acetamide, Sigma, St. Louis, MO, USA) at $25{ }^{\circ} \mathrm{C}$ for $16 \mathrm{~h}$. Silylated compounds were separated on a HP 7890A/5975D GC-MS. Further, $1.0 \mu \mathrm{L}$ sample was injected at $220{ }^{\circ} \mathrm{C}$ onto an Agilent HP-5MS column $(30 \mathrm{~m} \times 0.250 \mathrm{~mm}$ ID $\times 0.25 \mu \mathrm{m}$ film; Agilent Technologies, Santa Clara, CA, USA) at a flow rate of $1.2 \mathrm{~mL} / \mathrm{min}$. Compounds were separated by oven temperatures programmed from $40{ }^{\circ} \mathrm{C}(0.5 \mathrm{~min}$ hold $)$ to $220{ }^{\circ} \mathrm{C}$ (15 min final hold) at $15{ }^{\circ} \mathrm{C} / \mathrm{min}$. Compounds were identified by comparison of mass spectra and retention times with known standards (Contech Enterprises, Victoria, BC, Canada; Sigma, St. Louis, MO, USA). Compound amounts were quantified by comparison of characteristic SIM $\mathrm{m} / \mathrm{z}$ fragment peak areas with known amounts of standards. The QRP components coniferyl alcohol or linolenic acid were not quantified due to poor compound stability.

\subsection{Continuous monitoring of hive temperature}

Each colony's hive temperature was continuously monitored by a sensor (iButton, Thermochron, precision $\pm 0.06{ }^{\circ} \mathrm{C}$ ) attached to a top bar above the brood center (Meikle et al. 2016). Internal hive temperatures were continuously recorded every $15 \mathrm{~min}$ from $12 / 10 / 15$ to $4 / 5$ / 16 except during brief sensor exchanges and data downloads. Colony efforts at hive 
thermoregulation (daily hive temperature difference (DHTD)) were quantified by calculating the differences between internal hive temperatures and external ambient air temperatures. Our calculations were simplified by the fact that external air temperatures (range -4.8 to $23.1{ }^{\circ} \mathrm{C}$ ) remained below core hive temperatures. For this reason, we assumed that colony efforts at thermoregulation were mostly directed at heating. Then, 15-min hive temperature readings were averaged to yield hourly hive temperatures. The hourly hive temperature difference (in units of ${ }^{\circ} \mathrm{C} \times \mathrm{h}$ ) was calculated as the difference between the hourly hive temperature and the hourly external air temperature reading from a nearby automated weather station (see Online Resource 4). Hourly hive temperature differences were converted into a daily hive temperature difference (DHTD in units of ${ }^{\circ} \mathrm{C}$ $\times$ day) by dividing hourly readings by 24 and summing the hourly values from 0000 to $2300 \mathrm{~h}$ each day.

One limitation was that colony survivorship could only be confirmed during periodic hive inspections. Weak or queenless colonies often exhibited reduced thermal outputs that were indistinguishable from dead colonies. To exclude these colonies, comparisons were only made between colonies that survived the full interval. Dates when temperature sensors or colonies were not in place for $24 \mathrm{~h}$, such as during transport, sensor installation, or removal, were excluded from the analysis.

\subsection{Nosema ceranae infection rates}

$N$. ceranae infection rates of nest workers were compared using quantitative PCR (Bourgeois et al. 2010; Engel et al. 2013; see Online Resource 5). Total DNA was extracted from worker guts as described in Rothman et al. 2018. qPCR reactions for quantification of $N$. ceranae PCR products were performed as described in Bourgeois et al. 2010.

\subsection{Colony pesticide residues}

Nest workers, stored pollen, and honey were sampled from colonies at each of the four evaluation time points to assess pesticide exposures.
For each sample type, material was pooled equally from all colonies to provide $3 \mathrm{~g}$ material for a pesticide panel analysis (USDA AMS National Science Laboratory, Gastonia, NC, USA).

\subsection{Statistical analysis}

For each statistical test, comparisons were made by colony separately across forage site (site) and treatment (tmt) groups. Colony survivorship at the endpoint was compared by Pearson's chi-square test of independence. All other analyses were made on colonies repeatedly evaluated or sampled at successive time points. Statistical analyses were severely limited by high UF colony mortality during the last two intervals. For this reason, statistical comparisons were limited to colonies that survived the full interval through the first two time points (pre-forage and post-forage). Data sets were checked for normality by ShapiroWilk tests and examination of residuals (PROC UNIVARIATE, SAS 9.4, 2016). Total colony adult worker mass and HPG-soluble protein content were log-transformed and Nosema estimates were square root-transformed, then compared by repeated measures analysis (PROC MIXED, SAS 9.4, 2016; Meikle et al. 2016). Data sets that lacked normality (brood cell area, pollen cell area, QMP/ QRP releases, and individual worker mass) were compared by non-parametric Wilcoxon Rank Sum (tmt) or Kruskal-Wallis (site) tests (NPAR1WAY, SAS 9.4, 2016) conducted separately at each time point.

Thermoregulation efforts were estimated for each colony by summation of all DHTD recorded during the forage treatment interval (12/31/ 15 to $2 / 1 / 16$ ). Separately, we also examined whether colonies that survived or failed in almonds differed in their colony thermoregulation at the forage sites before entering almonds. Summed DHTD values were log-transformed and compared by two-sample $t$ test (tmt or colony survivorship/mortality in almonds) or one-way ANOVA (site) (PROC GLM, SAS 9.4, 2016) for each comparison. All statistical analyses were performed with SAS 9.4 (SAS Institute, Cary, NC, USA). 


\section{RESULTS}

\subsection{Colony survivorship}

Colony losses were highest in UF colonies ( $81 \%$ average, MACS $(88 \%)$, and MACN $(75 \%))$ and lowest in FS colonies (25\% average, RRE (38\%), and RRW (13\%); Figure 1; Pearson's chi-square test, $X^{2}=7.868, \mathrm{df}=3, p<0.05$ (site); $X^{2}=10.165, \mathrm{df}=1, p<0.05$ (tmt)). Fifty-eight percent of all losses were sustained in almonds while only 24 and $13 \%$ of losses occurred in the treatment sites and the holding yard.

\subsection{Colony performance}

Colony adult worker mass, brood cell area, and stored pollen cell area were similar across site and treatment groups (see Online Resources 6-9; repeated measures ANOVA (mass), $p>0.05$; for brood and stored pollen cell area, Wilcoxon Rank Sum (tmt) or Kruskal-Wallis test (site), $p>0.05$ ). Adult worker populations declined in almonds while brood populations increased almost sixfold from January to April. Stored pollen cells nearly doubled in colonies during almond pollination and were present throughout the experiment. During the forage treatments, FS sentinel colonies collected 3.1 to 3.5 times the amount of pollen collected by UF sentinel colonies.

\subsection{Individual nest worker mass and HPG protein content}

Colonies maintained adult nest workers of similar mass (Wilcoxon rank sum (tmt) or KruskalWallis test (site), $p>0.05$ ) and HPG protein content $\left(F_{3,23}=0.29, p=0.832\right.$ (site); $F_{1,25}=0.14$, $p=0.707$ (tmt)) at each time point (see Online Resources 7-8, 10-11).

\subsection{Transfers of QMP and QRP to retinue workers}

Queens from FS colonies released more of the QRP components methyl oleate $\left(\mathrm{MO} ; \mathrm{K}-\mathrm{W} X^{2}=\right.$ 16.834, df $=3, p<0.001$ (site); $Z=-4.031$, $p<0.001$ (tmt)), 1-hexadecanol (PA; K-W $X^{2}=$ 8.311, df $=3, p=0.040$ (site); $Z=-2.4926$, $p<0.013$ (tmt)), and the QMP component 4hydroxy-3-methoxyphenylethanol (HVA; K-W $X^{2}=8.107, \mathrm{df}=3, p=0.044$ (site); $Z=-$ $2.4359, p<0.015$ (tmt)) than queens from UF colonies during the post-forage evaluation (Figure 2; see Online Resources 12-13). Queen releases of four other QMP components $((E)-9$ oxodec-2-enoic acid (9-ODA), both enantiomers of (E)-9-hydroxydec-2-enoic acid (9-HDA), and methyl- $p$-hydroxybenzoate (HOB)) did not differ by site or treatment (see Online Resources 12-14).

\subsection{Continuous monitoring of hive temperature}

Colony thermoregulation (cumulative DHTD) during the forage treatment did not vary either by site $\left(F_{3,22}=0.55, p=0.651\right)$ or treatment $\left(F_{1,24}=0.11, p=0.746\right)$. On average, FS and UF colonies raised the hive temperature by 19.3 $\pm 1.1^{\circ} \mathrm{C} \mathrm{SE}$ and $18.7 \pm 1.1{ }^{\circ} \mathrm{C} \mathrm{SE}$ per day. However, colonies that failed in almonds had significantly lower average DHTD $\left(16.6 \pm 1.4^{\circ} \mathrm{C} \mathrm{SE} /\right.$ day) during forage treatment than colonies that survived $\left(20.1 \pm 0.9{ }^{\circ} \mathrm{C} \mathrm{SE} /\right.$ day; $F_{1,24}=4.86$, $p=0.037$; Figure $3 \mathrm{a}-\mathrm{d}$ ). Four of the five colonies that experienced major queen events (i.e., queen losses and supersedure attempts) showed sustained decreases in colony thermoregulation.

\subsection{Nosema ceranae infection rates}

Workers were moderately to highly infected by $N$. ceranae. Spore estimates increased from approximately $1.5 \times 10^{6}$ counts/bee in December to $1.9 \times 10^{6}$ counts/bee in March. Colony spore estimates from December to January did not significantly differ either by site $\left(F_{3,23}=1.97, p=\right.$ $0.147)$ or treatment $\left(F_{1,25}=3.79, p=0.063\right)$.

\subsection{Colony pesticide residues}

Before almond pollination, worker bees, stored pollen, and honey were largely free of detectable agrochemicals except for miticide treatments. Bees, stored pollen, and honey had very high levels of the miticide active ingredient thymol (up to $13,100 \mathrm{ppb}$ (bees), $750 \mathrm{ppb}$ (honey), and $1090 \mathrm{ppb}$ (pollen)), in 


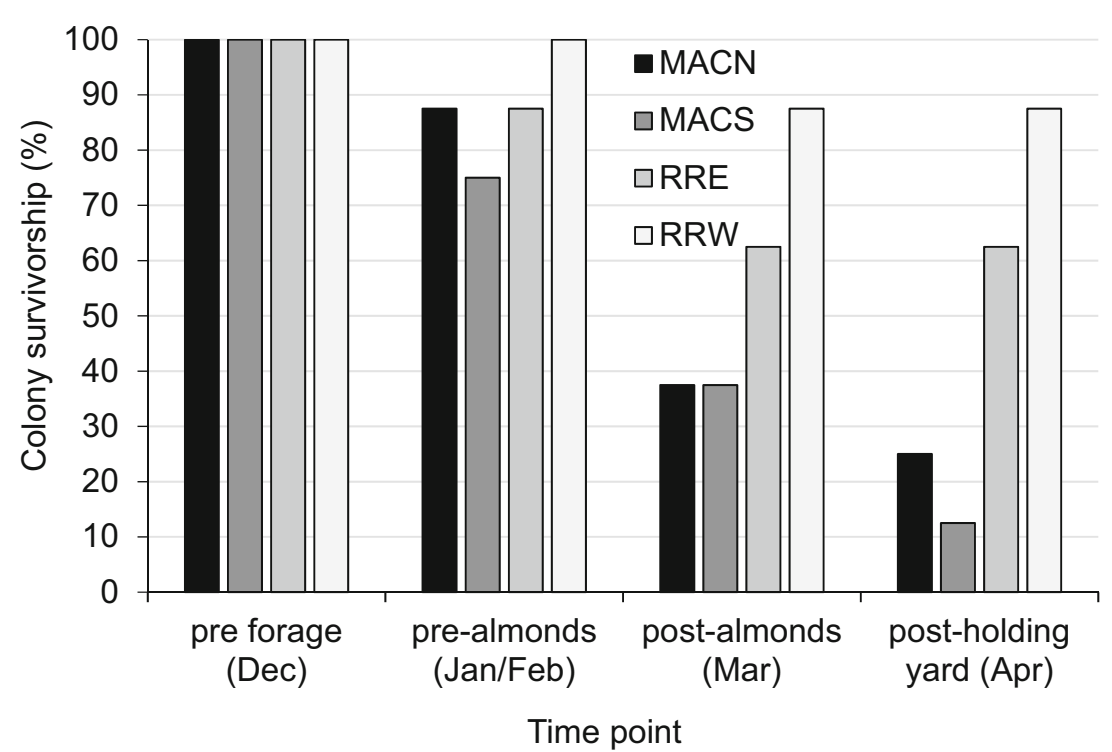

Fig. 1 Colony survivorship of forage supplemented (FS; RRE and RRW) and unsupplemented (UF; MACN and MACS) colonies at each evaluation time point ( $n=8$ colonies per site, $n=16$ colonies per treatment).

addition to $23.5 \mathrm{ppb}$ oxyfluoren (pollen and bees), $33.9 \mathrm{ppb}$ Carbendazim (pollen), and trace amounts of the miticide Amitraz breakdown product DMPF (honey). Stored pollen collected later in the holding yard had 56.4 ppb DDD, 13.7 ppb DDE, 218 ppb Ethion, $259 \mathrm{ppb}$ Iprodione, $67.9 \mathrm{ppb}$ Phosalone, and $1790 \mathrm{ppb}$ thymol.

\section{DISCUSSION}

Overwintering honey bees that engage in late winter pollination must rebuild worker populations under foraging stress (Perry et al. 2015). Mid-winter SF has been used not only to bolster worker numbers but also health, nutrition, and disease resistance before major foraging stresses

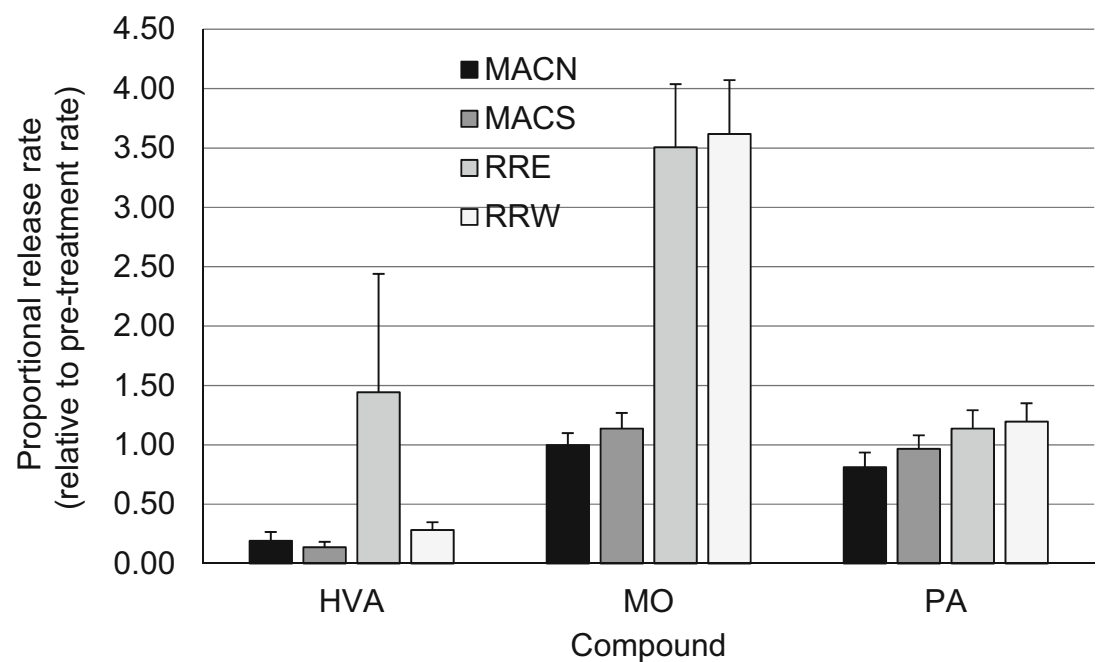

Fig. 2 Queen releases of the a QMP component 4-hydroxy-3-methoxyphenylethanol (HVA) and the QRP components, b 1-hexadecanol (PA), and $\mathbf{c}$ methyl oleate (MO) to retinue workers at the post-forage (January) evaluation time point, relative to the pre-treatment (December) release rates ( $n=6$ to 8 per site). 
occur (DeGrandi-Hoffman et al. 2016). In our experiment, SF improved colony survival but did not affect colony performance or worker quality in surviving colonies. FS and UF colonies entered almonds with similar numbers of workers, brood, and pollens. Critically, colony losses could not be attributed to absolute deprivation of pollen or nectar stores. Most colonies failed when forage was abundant and food stores were present.
Paradoxically, while foraging increases food stores, the stress of increased foraging can markedly shorten the worker lifespans (Perry et al. 2015; Münch et al. 2013).

Colony failures in almonds may not have been due to insufficient initial worker populations or food stores, but rather a reduced ability to replace workers. Most colonies that failed showed a decline in colony thermoregulation a few days to
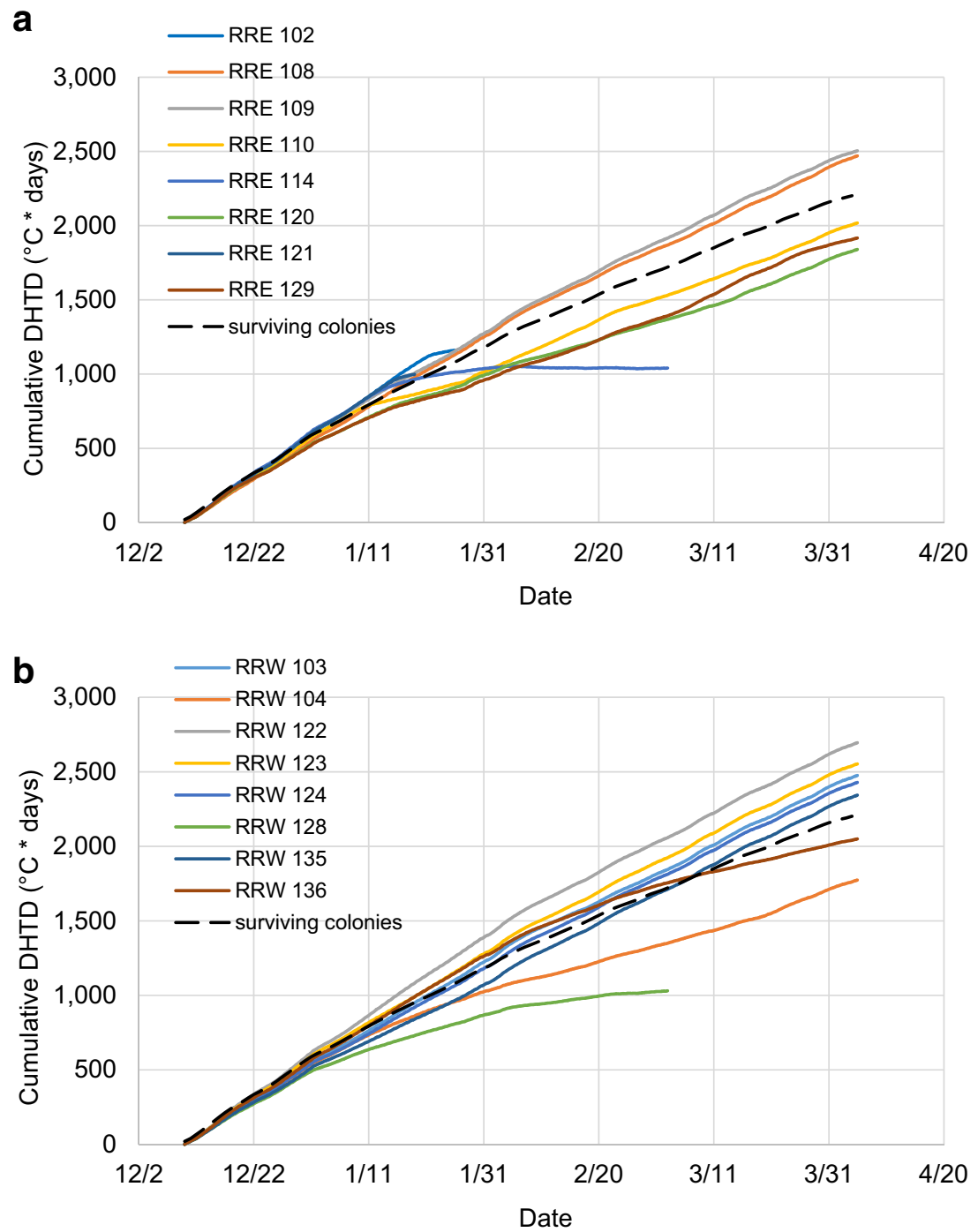

Fig. 3 Colony thermoregulation output (cumulative DHTD, or daily hive temperature difference) for individual colonies from FS a RRE and $\mathbf{b}$ RRW sites and UF $\mathbf{c}$ MACN and $\mathbf{d}$ MACS sites during the forage treatment. The average cumulative DHTD for colonies that survived to the experimental endpoint is shown by the black dashed line ( $n=6$ to 8 colonies per site). 

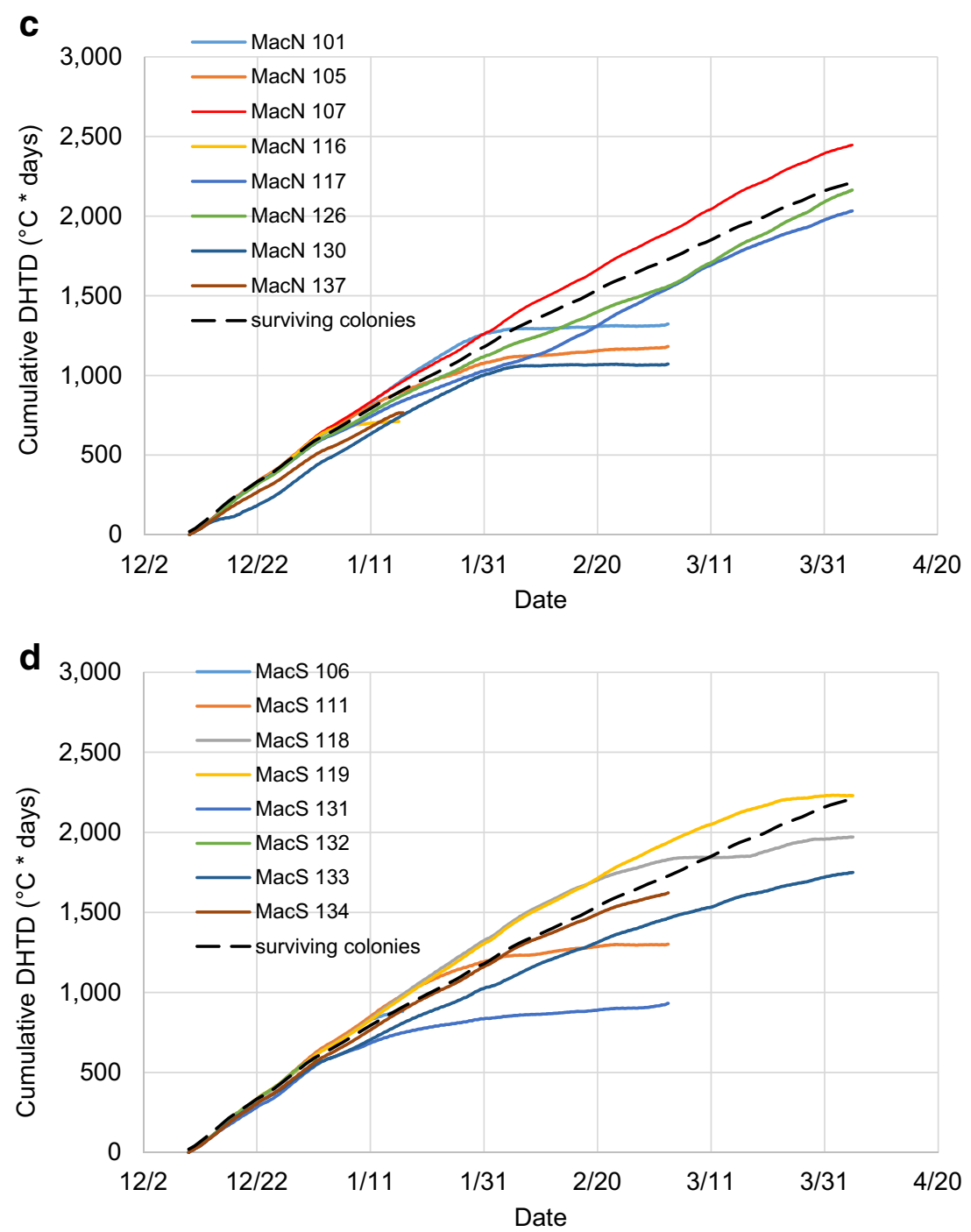

Fig. 3 (continued)

weeks before failure. Colony heating is often the largest energy outlay for overwintering bees and adults reduce thermoregulation during broodless periods to conserve sugar (Kronenberg and Heller 1982; Wang et al. 2016). However, a reduced ability to thermoregulate can severely impact a colony's ability to rear temperature-sensitive brood (Wang et al. 2016). Colonies are especially susceptible to brood-rearing disruption during the early spring transition when the need for replacement workers is critical (Münch et al. 2013). Ultimately, colonies that lose workers past a certain threshold may be subject to a "scissors effect" (Khoury et al. 2013), where worker populations becomes too small to effectively thermoregulate brood and dwindle despite food stores. In addition, forage availability acts as a signal to modulate brood production around dearth periods (Mattilla and Otis 2006, 2007).

Forage availability also affected queen-worker pheromone communication essential to queen care and retention (Kocher and Grozinger 2011; Pankiw et al. 1998; Keeling et al. 2003). Queens from FS colonies released more of one QMP 
(HVA) and two QRP (MO and PA) components than UF queens. Queens with reduced QMP may be superseded more often by workers - a risky process during early spring when drones are unavailable (Pettis et al. 1995, 1997; KostarelouDamianidou et al. 1995). Conspicuously, queen events such as supersedure or queen loss were associated with the reduced thermoregulation observed here in failed (predominantly UF) colonies.

One factor that may have contributed to rapid colony losses was high $N$. ceranae infection rates. The sharp onset of colony losses that occurred during almond pollination is consistent with excessive worker depletion by $N$. ceranae (Higes et al. 2008). Severe infections decrease task efficiencies and reduce worker lifespans - effects that may lead to colony failure (Kralj and Fuchs 2010; Maynack and Naug 2009; Naug and Gibbs 2009; Eiri et al. 2015). In addition, $N$. ceranae infection is known to alter queen QMP contents (Alaux et al. 2011). Notably, FS colonies had fewer colony losses than UF colonies despite similar infection levels. The difference may be partially due to the positive effects of dietary pollen on honey bee immunity and Nosema tolerance (Di Pasquale et al. 2013; Jack et al. 2016).

The use of mid-winter SF to bolster colonies is but one example of recent attempts to improve honey bee health through the forage landscape (Decourtye et al. 2010; Alaux et al. 2017; Döke et al. 2015; Requier et al. 2015; Smart et al. 2016). When crop systems are not flowering, pollinators rely on uncultivated plants blooming in field margins, irrigation systems, plantings, and natural areas (Ricigliano et al. 2018). Many of these alternative forage sources have been reduced as land use intensifies and management practices eliminate weeds and pest/pathogen reservoirs. Cultivated landscapes with limited forage alternatives have been linked to reductions in honey bee nutrition, colony performance, and colony survival (Alaux et al. 2017; Dolezal et al. 2016; Requier et al. 2015; Smart et al. 2016). SF is one of several management approaches used to increase floral nutrients during times of nutritional stress (Decourtye et al. 2010; DeGrandi-Hoffman et al. 2016; Lundin et al. 2017). Our study shows that modest plantings of mid-winter SF at high colony densities (50 colonies/ha forage) can improve colony survivorship during almond pollination. Markedly, SF does not compete with almond pollination nor need to be planted in orchards, and thus, need not interfere with almond management practices (Lundin et al. 2017). The use of SF before almond pollination could improve colony nutrition at a time when forage is scarce and migratory colonies are unavoidably crowded (Simone-Finstrom et al. 2016; Lundin et al. 2017).

\section{ACKNOWLEDGMENTS}

We would especially like to thank the Almond Board of California for funding this research. Almond orchards and apiary sites were provided courtesy of Gordon Wardell and Wonderful Pistachios and Almonds of California and the University of Arizona Agricultural Research Facilities. We would like to thank John Borden and Contech Enterprises for their gift of synthetic QMP mixture. We would also like to thank Aditya Vijay, Samantha Calle, Craig Goodall, and Austin Rodriguez for their technical assistance.

\section{AUTHOR'S CONTRIBUTION}

MJC, WM, and QM conceived this research and designed experiments. MJC, WM, QM, JR, and NB participated in the design and interpretation of the data. NB, MJC, EC, WM, QM, JR, ZR, and MW performed experiments and analysis. MJC, WM, QM, and JR wrote the paper and participated in the revisions of it. All authors read and approved the final manuscript.

\section{Data availability}

The datasets during and/or analyzed during the current study are available from the corresponding author on reasonable request.

\section{COMPLIANCE WITH ETHICAL STANDARDS}

Conflict of interest The authors declare that they have no conflict of interest. 


\section{OPEN ACCESS}

This article is distributed under the terms of the Creative Commons Attribution 4.0 International License (http://creativecommons.org/licenses/by/4.0/), which permits unrestricted use, distribution, and reproduction in any medium, provided you give appropriate credit to the original author(s) and the source, provide a link to the Creative Commons license, and indicate if changes were made.

Un butinage complémentaire avant floraison des amandiers améliore la survie de la colonie et modifie la communication par phéromone de la reine dans les colonies d'abeilles hivernantes

QMP / surveillance continue / température de la ruche / thermorégulation / Nosema ceranae

Das Angebot zusätzlicher Fouragieroptionen vor der Mandelblüte verbessert das Überleben der Völker und ändert die Königinnenpheromonkommunikation bei überwinternden Völkern

QMP / kontinuierliche Registrierung / Stocktemperatur / Thermoregulation / Nosema ceranae

\section{REFERENCES}

Alaux, C., Folschweiller, M., McDonnell, C., Beslay, D., Cousin, M., Dussaubat, C., Brunet, J.-L., Le Conte, Y. (2011) Pathological effects of the microsporidium Nosema ceranae on honey bee queen physiology (Apis mellifera ). J. Inverteb. Pathol. 106, 380-385

Alaux, C., Allier, F., Decourtye, A., Odoux, J.F., Tamic, T., Chabirand, M., Delestra, E., Decugis, F., Le Conte, Y., Henry, M. (2017) A "landscape physiology" approach for assessing bee health highlights the benefits of floral landscape enrichment and semi-natural habitats. Sci. Rep. 7, 40568

Al-Ghamdi, A., Al-Khaibari, A., Omar, M. (2011) Consumption rate of some proteinic diets affecting hypopharyngeal gland development in honeybee workers. Saudi J. Biol. Sci. 18, 73-77

Bourgeois, L., Rinderer, T.E., Beaman, L.D., Danka, R.G. (2010) Genetic detection and quantification of Nosema apis and $N$. ceranae in the honey bee. J. Invertebr. Pathol. 103, 53-58.

Brodschneider, R., Crailsheim, K. (2010) Nutrition and health in honey bees. Apidologie 41, 278-294.

Chen, Y.W., Chung, W.P., Chung-Hsiung, W., Solter, L.F., Huang, W.F. (2012) Nosema ceranae infection intensity highly correlates with temperature. J. Invertebr. Pathol. 111 , 264-267
Decourtye, A., Mader, E., Desneux, N. (2010) Landscape enhancement of floral resources for honey bees in agro-ecosystems. Apidologie 41, 264

DeGrandi-Hoffman, G., Wardell, G., Ahumada-Secura, F., Rinderer, T., Danka, R., Pettis, J. (2008) Comparisons of pollen substitute diets for honeybees: consumption rates by colonies and effects on brood and adult populations. J. Apic. Res. 47, 265-270

DeGrandi-Hoffman, G., Chen, Y., Huang, E., Huang, M. (2010) The effect of diet on protein concentration, hypopharyngeal gland development and virus load in worker honey bees (Apis mellifera L.). J. Insect Physiol. 56, 1194-1191

DeGrandi-Hoffman, G, Chen, Y., Rivera, R., Carroll, M., Chambers, M., Hidalgo, G., Watkins de Jong, E. (2016) Honey bee colonies provided with natural forage have lower pathogen loads and higher overwinter survival than those fed protein supplements. Apidologie 47, 186-196

Di Pasquale, G., Salignon, M., Le Conte, Y., Belzunces, L.P., Decourtye, A., Kretzschmar, A., Suchail, S., Brunet, J.L., Alaux, C. (2013) Influence of pollen nutrition on honey bee health: do pollen quality and diversity matter? PLOS One 8, e72016

Döke, M. A., Frazier, M., Grozinger, C. M. (2015) Overwintering honey bees: biology and management. Curr. Opin. Insect Sci. 10, 185-193

Dolezal, A., Carrillo-Tripp, J., Miller, W., Bonning, B., Toth, A. (2016) Intensively cultivated landscape and Varroa mite infestation are associated with reduced honey bee nutritional state. PLOS One 11, e0153531

Eiri, D., Suwannapong, G., Endler, M., Nieh, J. (2015) Nosema ceranae can infect honey bee larvae and reduces subsequent adult longevity. PLOS One 10, e0126330

Engel, P., Kwong, W.K., Moran, N.A. (2013) Frischella perrara gen. nov., sp. nov., a gammaproteobacterium isolated from the gut of the honeybee, Apis mellifera . Int. J. Syst. Evol. Microbiol. 63, 3646-3651

Fluri, P. Lüscher, M., Wille, H., Gerig, L. (1982) Changes in weight of the pharyngeal gland and haemolymph titres of juvenile hormone, protein and vitellogenin in worker honey bees. J. Insect Physiol. 28, 61-68

Harrison, J.M. (1987) Roles of individual honeybee workers and drones in colonial thermogenesis. J. Exp. Biol. 129, 53-61

Higes, M., Martin-Hernandez, R., Botias, C., Bailon, E.G., Gonzalez-Porto, A.V., Barrios, L., Del Nozal, M.J., Bernal, J.L., Jimenez, J.J., Palencia, P.G., Meana, A. (2008) How natural infection by Nosema ceranae causes honeybee colony collapse. Environ. Microbiol. 10, 2659-2669

Hrassnigg, N., Crailsheim, K. (1998) Adaptation of hypopharyngeal gland development to the brood status of honeybee (Apis mellifera L.) colonies. J. Insect Physiol. 44, 929-939

Jack, C., Uppala, S., Lucas, H., Sagili, R. (2016) Effects of pollen dilution on infection of Nosema ceranae in honey bees. J. Insect Physiol. 87, 12-19 
Keeling, C.I., Slessor, K.N., Higo, H.A., Winston, M.A. (2003) New components of the honey bee (Apis mellifera L.) queen retinue pheromone. P. Natl. Acad. Sci. USA 100, 4486-4491

Khoury, D.S., Barron, A.B., Myerscough, M.R. (2013) Modeling food and population dynamics in honey bee colonies. PLOS One 8, e59084

Kocher, S., Grozinger, C. (2011) Cooperation, conflict, and the evolution of queen pheromones. J. Chem. Ecol. 37, 1263-1275

Kostarelou-Damianidou, M., Thrasyvoulou, A., Tselios, D., Bladenopoulos, B. (1995) Brood and honey production of honey bee colonies requeened at various frequencies. J. Apicult. Res. 34, 9-14

Kralj, J., Fuchs, S. (2010) Nosema sp. influences flight behavior of infected honey bee (Apis mellifera) foragers. Apidologie 41, 21-28

Kronenberg, F., Heller, H.C. (1982) Colonial thermoregulation in honey bees (Apis mellifera). J. Comp. Physiol. 148, 65-76

Lundin, O., Ward, K., Artz, D. Boyle, N. Pitts-Singer, T., Williams, N. (2017) Wildflower plantings do not compete with neighboring almond orchards for pollinator visits. Environ. Entom. 46, 559-564

Mattila, H.R., Otis, G.W. (2006) Influence of pollen diet in spring on development of honey bee (Hymenoptera: Apidae) colonies. Econ. Entomol. 99, 604-613

Mattila, H.R., Otis, G.W. (2007) Dwindling pollen resources trigger the transition to broodless populations of long-lived honeybees each autumn. Ecol. Entomol. 32, 496-505

Mayack, C., Naug, D. (2009) Energetic stress in the honeybee Apis mellifera from Nosema ceranae infection. J. Invertebr. Pathol. 100, 185-188

Meikle W., Weiss M., Stilwell A. (2016) Monitoring colony phenology using within-day variability in continuous weight and temperature of honey bee hives. Apidologie 47, 1-14

Münch, D., Kreilbich, C.D., Amdam, G.V. (2013) Aging and its modulation in a long-lived worker caste of the honey bee. J. Exp. Biol. 216, 1638-1649

Naug, D., Gibbs, A. (2009) Behavioral changes mediated by hunger in honeybees infected with Nosema ceranae. Apidologie 40, 595-599

Naumann K., Winston M., Slessor K., Prestwich G., Webster F. (1991) Production and transmission of honey bee (Apis melifera L .) mandibular gland pheromone. Beh. Ecol. Sociobiol. 29, 321-332

Pankiw, T., Huang, Z, Winston, M. L., Robinson, G. E. (1998) Queen mandibular gland pheromone influences worker honey bee (Apis mellifera L.) foraging ontogeny and juvenile hormone titers. J. Insect Physiol. 44, 685-692

Perry, C.J., Sovik, E., Myerscough, M.R., Barron, A.B. (2015) Rapid behavioral maturation accelerates failure of stressed honey bee colonies. PNAS 112, 3427-3432

Pettis, J.S., Winston, M.L., Collins, A.M., (1995) Suppression of queen rearing in European and africanized honey bees
(Apis melifera L.) by synthetic queen mandibular gland pheromone. Insect. Soc. 42, 113-121

Pettis, J.S., Higo, H.A., Pankiw, T., Winston, M.L. (1997) Queen rearing suppression in the honey bee - evidence for a fecundity signal. Insect. Soc. 44, 311-322

Requier, F., Odoux, J.-F., Tamic, T., Moreau, N., Henry, M., Decourtye, A., Bretagnolle, V. (2015) Honey bee diet in intensive farmland habitats reveals an unexpectedly high flower richness and a major role of weeds. Ecol. Appl. 25, 881-890

Ricigliano, V., Mott, B., Floyd, A., Copeland, D., Carroll, M., Anderson, K. (2018) Honey bees overwintering in a southern climate: longitudinal effects of nutrition and queen age on colony-level molecular physiology and performance. Sci. Rep.-UK 8, 10475

Rollin, O., Bretagnolle, V., Decourtye, A., Aptel, J., Michel, N., Vaissière B, Henry, M. (2013) Differences of floral resource use between honey bees and wild bees in an intensive farming system. Agr. Ecosyst. Environ. 179, 78-89

Rothman, J. A., Carroll, M. J., Meikle, W. G., Anderson, K. E., McFrederick, Q. S. (2018) Longitudinal effects of supplemental forage on the honey bee (Apis mellifera) microbiota and inter- and intra- colony variability. Microb. Ecol. https://doi-org.ezproxy1.library.arizona. edu/10.1007/s00248-018-1151-y

SAS 9.4 (2016) SAS Institute, Cary, North Carolina, USA

Seeley, T.D. (1979) Queen substance dispersal by messenger workers in honeybee colonies. Behav. Ecol. Sociobiol. 5, 391-415

Seitz, N., Traynor, K.S., Steinhauer, N., Rennich, K., Wilson, M.E., Ellis, J.D, Rose, R., Tarpy, D.R., Sagili, R. R., Caron, D.M., Delaplane, K.S., Rangel, J., Lee, K., Baylis, K., Wilkes, J.T., Skinner, J.A., Pettis, J.S., D. vanEngelsdorp, (2015) A national survey of managed honey bee 2014-2015 annual colony losses in the USA. J. Apicult. Res. 54, 292-304

Simone-Finstrom, M., Li-Byarlay, H., Huang, M.H., Strand, M.K., Rueppell, O., Tarpy, D.R. (2016) Migratory management and environmental conditions affect lifespan and oxidative stress in honey bees. Sci. Rep. UK 6, 32023

Slessor, K.N., Kaminski, L.A., King, G.G., Borden, J.H., Winston, M.L. (1988) Semiochemical basis of the retinue response to queen honey bees. Nature 332, 354-356

Slessor, K.N., Kaminski, L.A., King, G., Winston, M.L. (1990) Semiochemicals of the honeybee queen mandibular glands. J. Chem. Ecol. 16, 851-860

Smart, M., Pettis, J., Rice, N., Browning, Z., Spivak, M. (2016) Linking measures of colony and individual honey bee health to survival among apiaries exposed to varying agricultural land use. PLOS One 11, e0152685

Standifer, L.N., Haydak, M.H., Mills, J.P., Levin, M.D. (1973) Influence of pollen in artificial diets on food consumption and brood production in honey bee colonies. Am. Bee J. 113, 94-95

Wang, Q., Xu, X., Zhu, X., Chen, L., Zhou, S., Huang, Z. Y., Zhou, B. (2016) Low-temperature stress during capped brood stage increases pupal mortality, misorientation, and adult mortality in honey bees. PLOS One 11, e0154547 